\title{
The Predictive Value of Proportional Evaluation Based on the Metabolic Activity of Cervical Lymph Nodes on PET/CT Imaging in Patients with Larynx Cancer
}

\author{
Larinks Kanserli Hastalarda PET/BT Görüntülemede Servikal Lenf Nodlarının Metabolik \\ Aktivitesine Dayanan Oransal Değerlendirmenin Prediktif Değeri

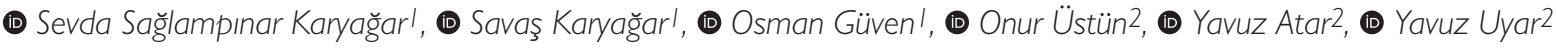 \\ IUniversity of Health Sciences Turkey, Istanbul Okmeydanı Training and Research Hospital, Clinic of Nuclear Medicine, Istanbul, Turkey \\ 2University of Health Sciences Turkey, Istanbul Okmeydanı Training and Research Hospital, Clinic of Otorhinolaryngology, Istanbul, Turkey
}

\begin{abstract}
Objectives: We aimed to evaluate the proportional values of maximum standardized uptake value (SUV $\left.{ }_{\max }\right)$ for cervical lymph nodes on ${ }^{18} \mathrm{~F}$-fluorodeoxyglucose (FDG) positron emission tomography/computed tomography (PET/CT) for prediction of the presence of metastasis in patients with larynx squamous cell cancer (LSCC).

Methods: This retrospective study involved 43 patients with LSCC. All patients underwent resection of the primary tumor and neck dissection within 4 weeks after undergoing ${ }^{18} \mathrm{~F}-\mathrm{FDG}$ PET/CT examinations. Receiver operating characteristic (ROC) analysis was performed to evaluate the

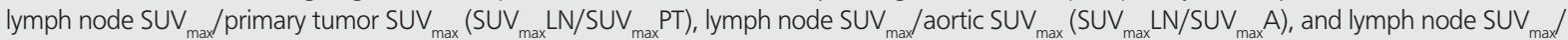
liver SUV ${ }_{\max }\left(S U V_{\text {max }} L N / S U V_{\text {max }} L\right)$ ratios for diagnosis of lymph node metastasis.

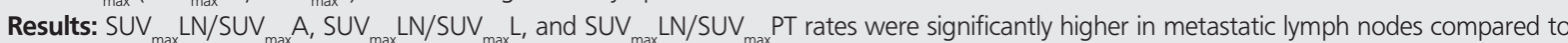
non-metastatic nodes. ROC analysis for metastasis showed that the cut-off thresholds were 3.87 for SUV $\max _{\mathrm{L}} \mathrm{LN} ; 1.78$ for SUV max $_{2} \mathrm{LN} / \mathrm{SUV} \mathrm{V}_{\max } \mathrm{A} ; 1.08$ for SUV max $_{\text {LN/SUV }}$ L L; and 0.36 for SUV max $_{\max }$ LNSUV PT. The diagnostic sensitivity, specificity and AUC were $83.7 \%, 77 \%, 0.856$ for SUV $_{\max }$ LN;

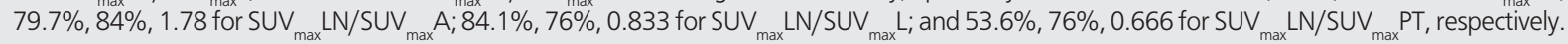

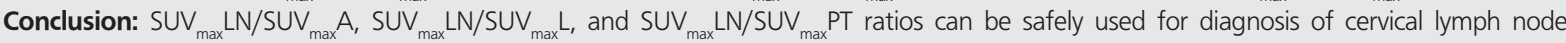
metastasis in patients with LSCC.

Keywords: Cervical lymph node, metabolic activity, larynx cancer, positron emission tomography/computed tomography
\end{abstract}

\section{Öz}

Amaç: ${ }^{18} \mathrm{~F}$-florodeoksiglikoz (FDG) pozitron emisyon tomografisi/bilgisayarlı tomografide (PET/BT) servikal lenf nodlarının maksimum standardize uptake değerine (SUV ${ }_{\text {maks }}$ ) dayalı oransal değerlerin skuamöz hücreli larenks kanserli (LSHK) hastalarda metastaz varlığını tahmin etmedeki gücünü değerlendirmeyi amaçladık.

Yöntem: Bu retrospektif çalısmaya LSHK olan 43 hasta alındı. Tüm hastalara ${ }^{18}$ F-FDG PET/BT görüntülemeden sonraki 4 hafta içinde primer tümör rezeksiyonu ve boyun diseksiyonu yapıldı. Metastatik lenf nodlarının tanısı açısından lenf nodu SUV $V_{\text {maks }}$ primer tümör $S U V_{\text {maks }}\left(S U V_{\text {maks }} L N /\right.$

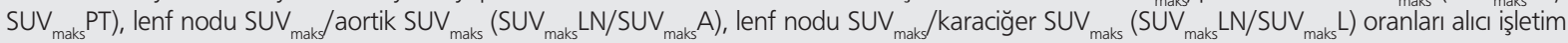
karakteristiği (ROC) analizi yapılarak değerlendirildi.

Bulgular: SUV ${ }_{\text {maks }}$ LN/SUV maks $_{1} \mathrm{~A}, \mathrm{SUV} \mathrm{m}_{\text {maks }} \mathrm{LN} / \mathrm{SUV} \mathrm{V}_{\text {maks }} \mathrm{L}$, SUV ${ }_{\text {maks }} \mathrm{LN} / \mathrm{SUV} \mathrm{V}_{\text {maks }} \mathrm{PT}$ oranları metastatik lenf nodlarında metastatik olmayanlara göre anlamlı

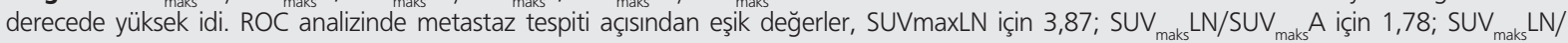
SUV $V_{\text {maks }} \mathrm{L}$ için 1,08; SUV $\mathrm{V}_{\text {maks }} \mathrm{LN} / \mathrm{SUV}$ maxPT için 0,36 olarak bulundu. Tanısal duyarllık, özgüllük ve AUC değerleri SUV maks $L N, S U V_{\text {maks }} L N / S U V_{\text {maks }} A$,

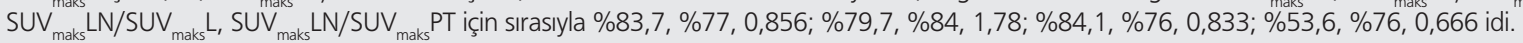

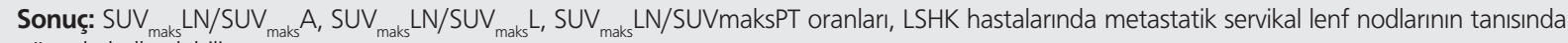
güvenle kullanilabilir.

Anahtar kelimeler: Servikal lenf nodu, metabolik aktivite, larenks kanseri, pozitron emisyon tomografisi/bilgisayarlı tomografi

Address for Correspondence: Osman Güven MD, University of Health Sciences Turkey, İstanbul Okmeydanı Training and Research Hospital, Clinic of Nuclear Medicine, istanbul, Turkey Phone: +90 5462608516 E-mail: osmngvn@gmail.com ORCID ID: orcid.org/0000-0001-5376-4993

Received: 05.09.2019 Accepted: 06.09.2019

${ }^{\circ}$ Copyright 2020 by Turkish Society of Nuclear Medicine

Molecular Imaging and Radionuclide Therapy published by Galenos Yayınevi. 


\section{Introduction}

${ }^{18} \mathrm{~F}$-fluorodeoxyglucose (FDG) positron emission tomography/ computed tomography (PET/CT) is being increasingly carried out to determine the stage and localization of metastatic disease in patients with larynx squamous cell cancer (LSCC). The correct diagnosis of metastatic cervical lymph nodes is important in terms of determining prognosis and providing adequate treatment. In clinical practice, CT and/or magnetic resonance imaging (MRI) are generally recommended for the assessment of tumor extension and cervical lymph node involvement (1).

Several studies in the literature reported that ${ }^{18} \mathrm{~F}$-FDG PET/ CT had reliable diagnostic value for a depiction of lymph node metastasis of head and neck squamous cell (HNSCC) compared with conventional CT/MRI $(2,3)$. Meta-analyses of ${ }^{18}$ F-FDG PET/CT showed that the pooled per-patient, per-neck-side, and per-neck-level sensitivities/specificities were $0.91 / 0.87,0.84 / 0.83$, and $0.80 / 0.96$, respectively. Across 13 studies (3460 neck levels) for which per-necklevel data were available, sensitivity and specificity were 0.84/0.96 respectively for ${ }^{18} \mathrm{~F}$-FDG PET/CT and $0.63 / 0.96$ for conventional imaging (CT and MRI), respectively (4).

Cut-off value of 2.5 for the maximum standardized uptake value ( $S U V_{\max }$ ) is used commonly to differentiate between benign and malignant lesions on ${ }^{18} \mathrm{~F}-\mathrm{FDG}$ PET/ $\mathrm{CT}$ imaging. But many biological and technical factors can affect SUV ${ }_{\max }$ value, such as patient's weight, blood glucose level, postinjection uptake time, respiratory motion, tumor behavior, lesion size, motion artefacts, variability of the scanner, image-reconstruction parameters and contrast agent used $(5,6)$. These factors may affect SUV values by $5 \%$ to $50 \%$ and cause false negativity or positivity (7).

In the literature, there are many studies on proportional values such as SUV $\max _{\max } \mathrm{LN} / \mathrm{SUV}_{\max } \mathrm{PT}$, SUV $\mathrm{m}_{\max } \mathrm{LN} / \mathrm{SUV} \mathrm{V}_{\max } \mathrm{A}$, and $S U V_{\max } L N / S U V_{\max } L$ for the prediction of metastatic lymph nodes in various malignancies, mainly lung cancer and breast cancer. However, the number of studies about LSCC is limited $(8,9,10,11,12)$. In this study, we aimed to evaluate the proportional values of the SUV $V_{\max }$ for cervical lymph nodes on ${ }^{18} \mathrm{~F}-\mathrm{FDG}$ PET/CT imaging for the prediction of the presence of metastasis in patients with LSCC.

\section{Materials and Methods}

This retrospective study involved 43 patients (42 men, 1 woman; mean age $=60.20 \pm 8.12$ years, range $=46-83$ ) with LSCC.

The following criteria were defined for patient selection:

- Patients with diagnosis ofprimary LSCC made by a biopsy.
- Patients who did not undergo any treatment for LSCC before ${ }^{18} \mathrm{~F}-\mathrm{FDG}$ PET/CT imaging and had no secondary malignancy.

- Patients who did not undergo any diagnostic excisional or incisional cervical lymph node biopsy for metastasis evaluation before ${ }^{18} \mathrm{~F}-\mathrm{FDG}$ PET/CT imaging.

- Patients who underwent resection of the primary tumor and neck dissection within 4 weeks after undergoing ${ }^{18} \mathrm{~F}$-FDG PET/CT imaging.

${ }^{18} \mathrm{~F}-\mathrm{FDG} \mathrm{PET} / \mathrm{CT}$ imaging was performed at our institution between November 2013 and January 2018. Ethics Committee Approval was obtained from Okmeydan Training and Research Hospital Ethics Committee with the decision number "1066" and date "12.04.2018". The written informed consent was obtained from all patients at the time of imaging

${ }^{18} \mathrm{~F}-\mathrm{FDG}$ PET/CT studies were carried out using an integrated PET/CT scanner, which consisted of a full-ring HI-REZ LSO PET and a 6-slice CT (Siemens Biograph 6; Siemens, Chicago, USA). All patients were instructed to fast for at least $6 \mathrm{~h}$ before the ${ }^{18} \mathrm{~F}-\mathrm{FDG}$ injection. Blood glucose levels were measured before the study and the injection was given only when the blood glucose levels were below $11.11 \mathrm{mmol} / \mathrm{L}$. The patients were injected with 370 to $555 \mathrm{MBq}{ }^{18} \mathrm{~F}-\mathrm{FDG}$, according to body weight. After 60 minutes of waiting on a semireclined relaxed chair, the patients were imaged using an integrated PET/CT scanner. The CT portion of the study was performed without injection of intravenous contrast medium to define anatomical landmarks and attenuate correction on PET images. CT was acquired first with the following parameters: $50 \mathrm{mAs}, 140 \mathrm{kV}$, and $5 \mathrm{~mm}$ section thickness. Whole-body CT was performed in a craniocaudal direction. PET images were acquired in a three-dimensional mode, from the vertex to mid-thigh, with six to eight bed positions of $3 \mathrm{~min}$ each, and PET data were collected in a caudocranial direction. Image reconstruction used "ordered subsets expectation maximization" algorithm of 2 iterations and 8 subsets. Image analysis was carried out on the Esoft multimodality computer platform (Siemens Medical Solutions, Erlangen, Germany). ${ }^{18} \mathrm{~F}-\mathrm{FDG}$ PET/CT images were retrospectively interpreted by 3 experienced nuclear medicine physicians. The observers were blinded to the results of preoperative diagnostic imaging examinations such as MRI or ultrasonography and to the histopathological evidence of lymph node dissections. All cervical lymph nodes on CT which increased tracer uptake compared with background activity were accepted as metastatic. Semi-quantitative analysis of ${ }^{18} \mathrm{FDG}$ uptake was performed, through creation of a region of interest (ROI) over the primary lesion and lymph nodes. SUV ${ }_{\max }$ was also 
determined by manually placing a cylindrical ROI over the arcus aorta and right lobe of the liver. Lymph node SUV ${ }_{\text {max }}$ values were divided by the SUV ${ }_{\text {max }}$ of the primary tumour, arcus aorta (mediastinal blood pool) and liver to calculate the following:

- Lymph node SUV ${ }_{\text {max }} /$ primary tumour SUV $V_{\text {max }}\left(S U V_{\max } L N /\right.$ SUV ${ }_{\max } \mathrm{PT}$ )

- Lymph node SUV max $_{\text {a aortic SUV }}\left(S_{\max }\left(S U V_{\max }\right.\right.$ LN/SUV $\left.\max _{\max } \mathrm{A}\right)$

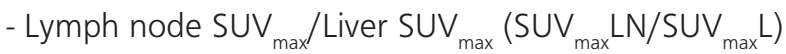

Operations were performed in our head and neck surgical clinic based on clinical and imaging findings. Modified radical neck dissection was performed in all patients. Lymph nodes and tumors were dissected from the specimens and stained with hematoxylin and eosin for histologic analysis. Serial histologic sections were used. We compared results of preoperative examinations using ${ }^{18} \mathrm{~F}$-FDG PET/CT with those of the corresponding histopathologic examinations. If one lymph node showed increased uptake on ${ }^{18} \mathrm{~F}-\mathrm{FDG}$ $\mathrm{PET} / \mathrm{CT}$ images and had some findings on CT such as $\geq 10 \mathrm{~mm}$ diameter or round shape or hypoechogenicity or irregular margin or loss of fatty hilum findings and if histopathology showed lymph node with metastasis in the same neck level, this lymph node was accepted as a true positive finding for ${ }^{18} \mathrm{~F}-\mathrm{FDG}$ PET/CT. If metastatic lymph node number on histopathology was lower than lymph node numbers that were accepted as metastatic on ${ }^{18} \mathrm{~F}$-FDG PET/CT, the lymph node showing the lowest uptake was accepted as false positive. If metastatic lymph node number on histopathology was higher than lymph node number accepted as metastatic on ${ }^{18} \mathrm{~F}-\mathrm{FDG}$ PET/CT, it was recorded as false-negative lymph node for ${ }^{18} \mathrm{~F}-\mathrm{FDG}$ $\mathrm{PET} / \mathrm{CT}$.

\section{Statistical Analysis}

While evaluating the findings of the study, IBM SPSS Statistics 22 program (IBM SPSS, Turkey) was used for statistical analysis. The normal distribution of the parameters was evaluated by the Shapiro-Wilk test and it was found that the parameters did not show normal distribution. The Mann-Whitney $U$ test was used to compare the parameters between the two groups. Receiver operating characteristic (ROC) curve analysis was performed to identify the best cut-off value and to evaluate whether SUV ${ }_{\text {max }}$ LN and also SUV max $_{\text {L }}$ LN/SUV ${ }_{\text {max }}$ PT, SUV ${ }_{\text {max }} L N$ / SUV ${ }_{\text {max }} A$ and $S U V_{\text {max }} L N / S U V_{\text {max }}$ L ratios provided diagnosis of lymph node metastasis. For the calculation of sensitivity and specificity, the screening test was used. A $p$ value $<0.05$ was accepted as statistically significant.

\section{Results}

Patients general characteristics are given in Table 1 . Histopathological examination revealed 71 metastatic lymph nodes in 21 patients (mean=3.5; range=1-12). On ${ }^{18} \mathrm{~F}-\mathrm{FDG}$ PET/CT imaging, 68 lymph nodes showing

\begin{tabular}{|l|l|}
\hline Table 1. General characteristics of patients \\
\hline Total number of patients ( $\mathbf{n})$ & 43 \\
\hline Laryngectomy & 14 \\
\hline -Partial & 29 \\
\hline -Total & \multicolumn{2}{|l|}{} \\
\hline Neck dissection & 39 \\
\hline -Bilateral & 4 \\
\hline -Unilateral & \\
\hline Histopathologic evaluation of lymph nodes & 21 \\
\hline -Metastatic & 22 \\
\hline -Nonmetastatic & \\
\hline
\end{tabular}

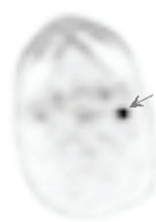

A

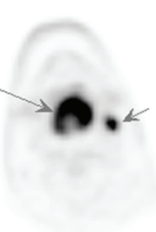

C

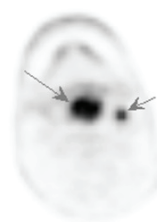

$E$

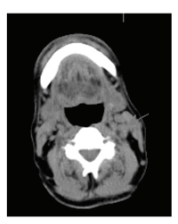

B

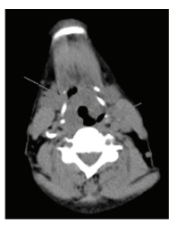

D

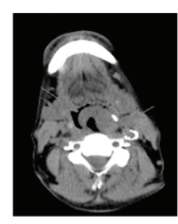

$\mathrm{F}$
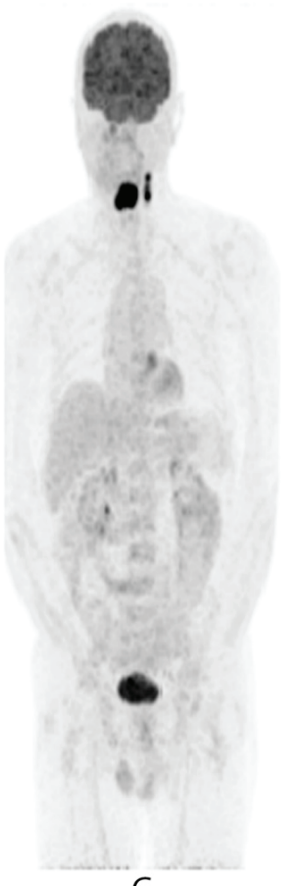

G
Figure 1. ${ }^{18} \mathrm{~F}-\mathrm{FDG}$ PET/CT with axial slice PET $(\mathrm{A}, \mathrm{C}, \mathrm{E})$, axial slice $C T(B$, $D, F)$ and whole-body PET (F) images of a 59-year-old patient with larynx squamous cell cancer. ${ }^{18} \mathrm{~F}$-FDG PET/CT imaging showed primary laryngeal hypermetabolic lesion and hypermetabolic lymph nodes at left upper and middle jugular region compatible with metastasis. He underwent total laryngectomy and left modified neck dissection. Histopathological examination revealed three metastatic lymph nodes

FDG: Fluorodeoxyglucose, PET: Positron emission tomography, CT: Computed tomography 
Table 2. Diagnostic performance of the quantitative metabolic parameters

\begin{tabular}{|c|c|c|c|c|}
\hline & $\begin{array}{l}\text { Metastatic } \\
(n=69)\end{array}$ & $\begin{array}{l}\text { Non-metastatic } \\
(n=25)\end{array}$ & $\begin{array}{l}\text { Total } \\
(n=94)\end{array}$ & $\mathbf{p}$ \\
\hline & Avg $\pm S D$ (median) & Avg $\pm S D$ (median) & Avg \pm SD (median) & \\
\hline SUV $_{\max }$ LN & $11.51 \pm 7.99(10.14)$ & $4.16 \pm 3.96(3.25)$ & $9.48 \pm 7.71(5.87)$ & $0.000^{*}$ \\
\hline SUV $_{\max }$ LN/SUV max L & $2.77 \pm 1.73(2.5)$ & $1.21 \pm 1.03(0.8)$ & $2.35 \pm 1.72(1.6)$ & $0.000^{*}$ \\
\hline SUV $_{\max }$ LN/SUV ${ }_{\max } A$ & $4.13 \pm 2.71(3.5)$ & $1.82 \pm 1.69(1.2)$ & $3.51 \pm 2.68(2.3)$ & $0.000 *$ \\
\hline SUV max $_{\text {ax }}$ LN/SUV max $_{\max }$ PT & $0.48 \pm 0.52(0.4)$ & $0.3 \pm 0.23(0.2)$ & $0.43 \pm 0.47(0.3)$ & $0.014^{*}$ \\
\hline
\end{tabular}

increased FDG uptake were evaluated by histopathological examination and metastasis was detected (Figure 1), but the histopathological examination of 26 lymph nodes showing ${ }^{18} \mathrm{~F}-\mathrm{FDG}$ involvement showed no metastasis. There was no pathological involvement on ${ }^{18} \mathrm{~F}-\mathrm{FDG} \mathrm{PET} / \mathrm{CT}$ in 3 lymph nodes with metastasis in 1 patient.

In patients with metastatic lymph nodes, the primary tumor SUV $_{\text {max }}$ values were significantly higher than non-metastatic patients $(26.76 \pm 10.43$ vs $17.73 \pm 8.14 ; p=0.001)$. Mean

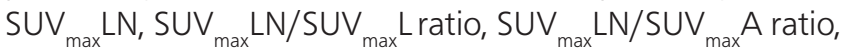
and SUV ${ }_{\max }$ LN/ SUV ${ }_{\text {max }}$ PT ratio were significantly higher in patients with metastatic lymph nodes than non-metastatic nodes (Table 2).

For diagnosis of lymph node metastasis with ROC analysis, the cut-off point for SUV max $_{\text {LN }}$ was 3.87 (AUC 0.856 , p: 0.000 ) with the sensitivity of $83.7 \%$, specificity $77 \%$, positive predictive value (PPV) $89.1 \%$ and negative predictive value (NPV) 58\% (Figure 2). The cut-off point

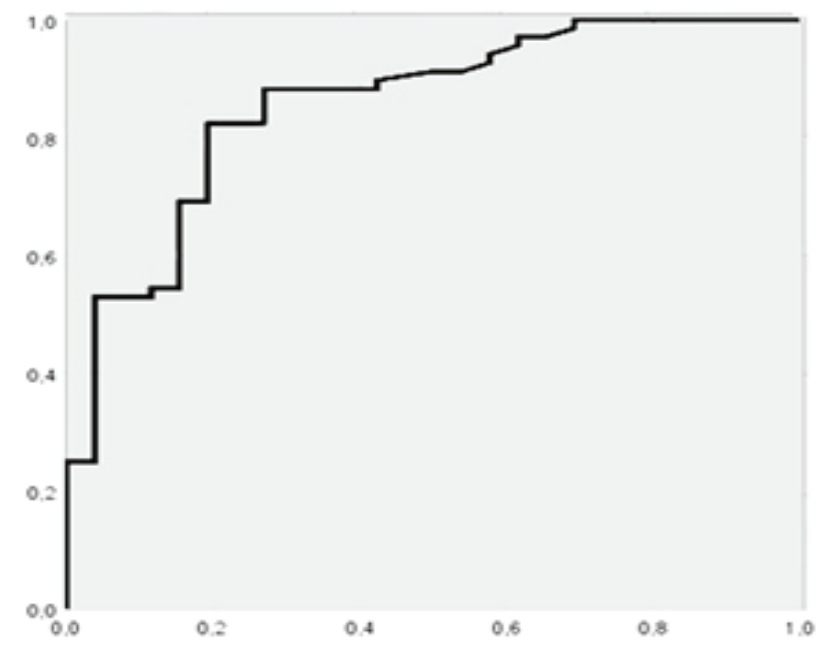

Figure 2. ROC curve for $S U V_{\text {max }} L N$ in the diagnosis of lymph node metastasis

ROC: Receiver operating characteristic, SUV ${ }_{\text {max }}$ : Maximum standardized uptake value, LN: Lymph node for SUV ${ }_{\max }$ LN/SUV ${ }_{\max }$ L was 1.08 (AUC 0.833, $p=0.000$ ), with a sensitivity of $84.1 \%$, specificity of $76 \%$, PPV $90.6 \%$, and NPV 63.3\% (Figure 3). The cut-off point for SUV max $_{\text {LN/ }}$ SUV ${ }_{\text {max }} A$ was 1.78 (AUC 0.822, $p=0.000$ ) for the diagnosis of lymph node metastasis. The sensitivity of this value was $79.7 \%$, specificity was $84 \%$, PPV was $93.2 \%$, and NPV was $60 \%$ (Figure 4). The cut-off point for SUV max $_{\text {LN/SUV }}$ PT was 0.36 (AUC 0.666, p: 0.014) for the diagnosis of lymph node metastasis, with a sensitivity of $53.6 \%$, specificity $76 \%$, PPV 86.1\%, and NPV 37.3\% (Figure 5). When SUV $_{\max } \mathrm{LN}>2.5$ was taken as a criterion for the detection of metastatic lymph nodes, the sensitivity was $95.7 \%$, the specificity was $26.9 \%$, PPV was $78 \%$, and NPV was $70 \%$.

\section{Discussion}

Quantitative data obtained using ${ }^{18} \mathrm{~F}-\mathrm{FDG}$ PET/CT can be useful for lymph node assessment in addition to visual evaluation. In general practice, if a lymph node shows ${ }^{18}$ F-FDG uptake and SUV ${ }_{\text {max }}$ value is more than 2.5 , it is more

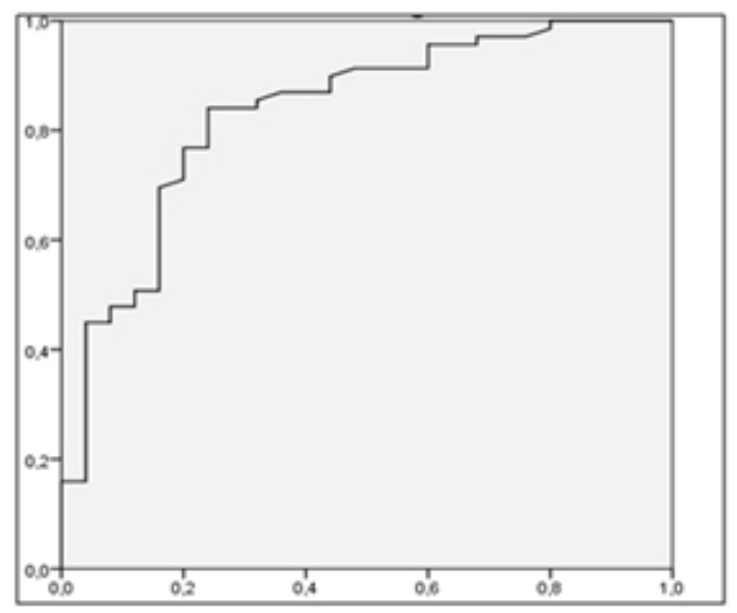

Figure 3. ROC curve for SUV $V_{\max } L N / S U V_{\max } L$ in the diagnosis of lymph node metastasis

ROC: Receiver operating characteristic, SUV ${ }_{\text {max }}$ : Maximum standardized uptake value, LN: Lymph node, L: Liver 


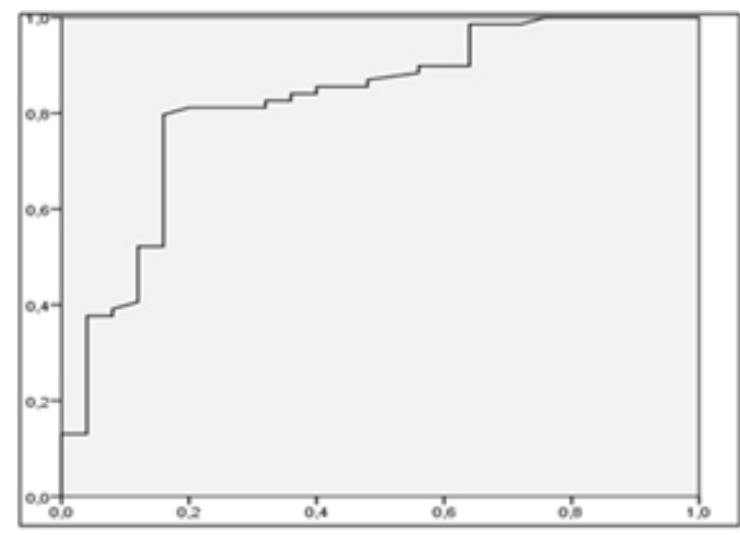

Figure 4. ROC curve for $S U V_{\max } L N / S U V_{\max } A$ in the diagnosis of lymph node metastasis

ROC: Receiver operating characteristic, SUV max $_{\text {: }}$ Maximum standardized uptake value, LN: Lymph node, A: Aortic

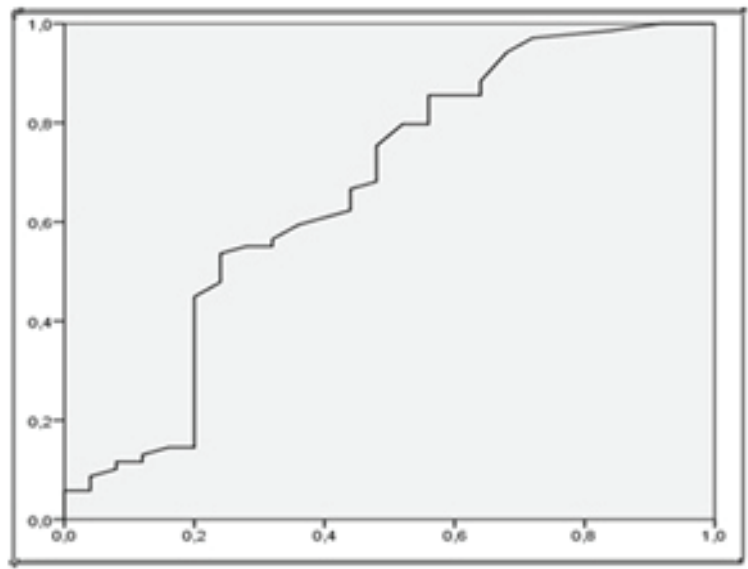

Figure 5. ROC curve for SUVmaxLN/SUVmaxPT in the diagnosis of lymph node metastasis

ROC: Receiver operating characteristic, SUVmax: Maximum standardized uptake value, LN: Lymph node, PT: Primary tumor

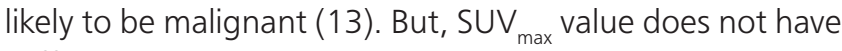
sufficient diagnostic capability to detect metastatic lymph nodes in head and neck cancer. In our study, if SUV max $_{\text {max }}>2.5$ was taken as the criterion for detection of metastatic lymph node, the sensitivity would be $95.7 \%$ and the specificity would be $26.9 \%$. To increase diagnostic accuracy for detecting metastatic lymph nodes, different lymph node SUVmax cut-off value and proportional ratios reproduced from lymph node SUVmax are used $(12,14,15,16,17)$.

In our study, the mean SUV ${ }_{\max }$ values, SUV max $_{\max } L N / S U V_{\max } \mathrm{L}$ ratio, SUV max $_{\text {ax }}$ LN/ SUV max $A$ ratio, and SUV max $_{\max }$ LN/SUV ${ }_{\max } P T$ ratio of metastatic lymph nodes were significantly higher than non-metastatic lymph nodes. In the ROC analysis, the cut-off point for SUV max $_{\text {max }}$ LN was 3.87 for the diagnosis of lymph node metastasis, with a sensitivity of $83.7 \%$ and specificity of $77 \%$. A study by Marshall et al. (16) included 114 patients with head and neck cancer and found that SUV $_{\max }$ cut-off was 3.9 and that yielded a sensitivity of $85 \%$ and specificity of $73 \%$. Suenaga et al. (17) used a SUV $_{\max }$ cut-off value of 3.65 and found that sensitivity, specificity, and accuracy of ${ }^{18}$ F-FDG PET/CT on a level by level basis were 72.9, 96.8, and 92.1\%, while sensitivity, specificity, and accuracy of CT were $52.9,98.6$, and $89.6 \%$, respectively (17).

In our study, cut-off values for SUV max $_{\max }$ LN SUV $\mathrm{max}_{\max }$ and SUV $V_{\max }$ LN/ SUV max $_{\text {ax }}$ A were 1.08 and 1.78, respectively. The sensitivity and specificity for these cut-off values were $84.1 \%$ $76 \%$ and $79.7 \%-84 \%$, respectively. These proportional values were proven to have higher AUC compared to SUV ${ }_{\max }$ LN/SUV ${ }_{\max }$ PT ratio and have high diagnostic power for the diagnosis of metastatic lymph node. We think that this situation is due to the variance in SUV ${ }_{\max }$ of the primary tumor due to the size or histopathological features of the tumor. The specificity of all 3 proportional values we examined in our patient group was higher when $S U V_{\max }$ $>2.5$ criterion was used. Lim et al. (12) studied 74 patients with HNSCC and found that nodal SUV max $_{\max } \geq 3.16$ yielded a sensitivity of $74.4 \%$ and specificity of $84.9 \%$ in detecting metastatic nodes and also that nodal SUV ${ }_{\max } \mathrm{LN} / \mathrm{SUV} \mathrm{max}_{\max } \mathrm{L}$ ratio $\geq 0.90$ yielded a sensitivity of $74.1 \%$ and specificity of $93.4 \%$.

\section{Study Limitations}

There are some limitations of the present study. It was a retrospective study with a limited number of patients. As the study was retrospective, there were technical impediments to the matching of the lymph nodes detected on ${ }^{18} \mathrm{~F}-\mathrm{FDG}$ $\mathrm{PET} / \mathrm{CT}$ imaging and histopathological examination. Because the precise spatial correlation between ${ }^{18} \mathrm{~F}-\mathrm{FDG}$ $\mathrm{PET} / \mathrm{CT}$ and histopathology was impossible and one to one matching between them showed increased uptake on ${ }^{18} \mathrm{~F}-\mathrm{FDG}$ PET/CT and metastatic lymph nodes on histopathologic evaluation could not be attributed due to the retrospective study design; analysis of results of the study should use this model. Therefore, there is a need for prospective studies with larger samples.

\section{Conclusion}

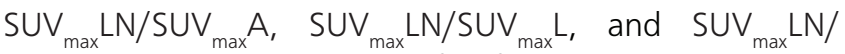
SUV ${ }_{\text {max }}$ PT ratios can be used safely for diagnostic evaluation of metastasis in cervical lymph nodes on ${ }^{18} \mathrm{~F}-\mathrm{FDG}$ PET/CT imaging in patients with LSCC. 


\section{Ethics}

Ethics Committee Approval: Ethics Committee Approval was obtained from Okmeydanı Training and Research Hospital Ethics Committee with the decision number "1066" and date "12.04.2018".

Informed Consent: The written informed consent was obtained from all patients at the time of imaging.

Peer-review: Externally and internally peer-reviewed.

\section{Authorship Contributions}

Surgical and Medical Practices: O.Ü., Y.A., Y.U., Concept: S.S.K., S.K., O.G., Design: S.S.K., S.K., O.G., Data Collection or Processing: S.S.K., S.K., O.G., O.Ü., Y.A., Y.U., Analysis or Interpretation: S.S.K., S.K., O.G., Literature Search: S.S.K., S.K., O.G., Writing: S.S.K., S.K., O.G.

\section{References}

1. Steuer CE, El-Deiry M, Parks JR, Higgins KA, Saba NF. An Update on Larynx cancer. CA Cancer J Clin 2017; 67:31-50.

2. Kim SY, Kim JS, Doo H, Lee H, Lee JH, Cho KJ, Choi SE, Nam SY, Roh JL. Combined [18F] fluorodeoxyglucose positron emission tomography and computed tomography for detecting contralateral neck metastases in patients with head and neck squamous cell carcinoma. Oral Oncol 2011;47:376-380.

3. Ceylan Y, Ömür Ö, Hatipoğlu F. Contribution of ${ }^{18 F-F D G ~ P E T / C T ~ t o ~}$ staging of Head and Neck Malignancies. Mol Imaging Radionucl Ther 2018;27:19-24.

4. Sun $R$, Tang $X$, Yang $Y$, Zhang C. ${ }^{18} F-F D G$ PET/CT for the detection of regional nodal metastasis in patients with head and neck cancer: a metaanalysis. Oral Oncol 2015;51:314-320.

5. Adams MC, Turkington TG, Wilson JM, Wong TZ. A systematic review of the factors affecting accuracy of SUV measurements. Am J Roentgenol 2010;195:310-320.

6. Boellaard R. Standards for PET image acquisition and quantitative data analysis. J Nucl Med 2009;50(Suppl 1):11-20.

7. Weiss GJ, Korn LR. Interpretation of PET Scans: Do Not Take SUVs at Face Value. J Thoracic Oncol 2012;7:1744-1746.
8. Mattes MD, Moshcinsky AB, Ahsanuddin S, Rizk NP, Foster A, Wu AJ, Ashamalla H, Weber WA, Rimner A. Ratio of Lymph Node to Primary Tumor SUV on PET/CT Accurately Predicts Nodal Malignancy in NonSmall Cell Lung Cancer. Clin Lung Cancer 2015;16:253-258.

9. Lee AY, Choi SC, Jung KP, Park JS, Lee SM, Bae SK. Characteristics of Metastatic Mediastinal Lymph Nodes of Non-Small Cell Lung Cancer on Preoperative F-18 FDG PET/CT. Nucl Med Mol Imaging 2014;48:41-46.

10. Sun YW, Choi YC, Song Y. Prediction of Axillary Nodal Status according to the Axillary Lymph Node to Primary Breast Tumor Maximum Standardized Uptake Value Ratio on ${ }^{18} \mathrm{~F}$-fluorodeoxyglucose Positron Emission Tomography/ Computed Tomography. J Breast Dis 2016;4:9299.

11. Gedik GC, Kara PO, Kara T, Sari O, Kara F. Evaluation of FDG uptake in pulmonary hila with FDG PET/CT and contrast-enhanced $\mathrm{CT}$ in patients with thoracic and non-thoracic tumors. Ann Nucl Med 2010;24:593599.

12. Lim RSM, Ramdave S, Beech S, Billah B, Karim MN, Smith JA, Safdar A, Sigston E. Utility of SUVmax on ${ }^{18} \mathrm{~F}-\mathrm{FDG}$ PET in detecting cervical nodal metastases. Cancer Imaging 2016;16:39-47.

13. Plaxton NA, Brandon DC, Corey AS, Harrison CE, Karagulle Kendi AT, Halkar RK, Barron BJ. Characteristics and Limitations of ${ }^{18} \mathrm{~F}-\mathrm{FDG}$ PET/ CT for Imaging of Squamous Cell Carcinoma of the Head and Neck: A Comprehensive Review of Anatomy, Metastatic Pathways, and Image Findings. AJR Am J Roentgenol 2015;205:519-531.

14. Matsubara R, Kawano S, Chikui T, Kiyosue T, Goto $Y$, Hirano M, Jinno T, Nagata T, Oobu K, Abe K, Nakamura S. Clinical significance of combined assessment of the maximum standardized uptake value of ${ }^{18} \mathrm{~F}-\mathrm{FDG}$ PET with nodal size in the diagnosis of cervical lymph node metastasis of oral squamous cell carcinoma. Acad Radiol 2012;19:708-717.

15. Murakami R, Uozumi H, Hirai T, Nishimura R, Shiraishi S, Ota K, Murakami D, Tomiguchi S, Oya N, Katsuragawa S, Yamashita Y. Impact of ${ }^{18} \mathrm{~F}-\mathrm{FDG}$ PET/CT imaging on nodal staging for head-and-neck squamous cell carcinoma. Int J Radiat Oncol Biol Phys 2007;68:377-382.

16. Marshall RA, Som PD, Uliel L, Buckstein M, Gupta V, Miles B, Gandikota N, Corcuera-Solano I, Misiukiewicz K, Sikora AG, Kostakoglu L. Combined Evaluation of ${ }^{18} \mathrm{~F}-\mathrm{FDG}$ PET/CT and CT Imaging Characteristics of Cervical Lymph Nodes to Increase the Interpretation Accuracy for Nodal Metastatic Involvement in Head and Neck Cancer. Otolaryngol (Sunnyvale) 2015;5:213.

17. Suenaga $Y$, Kitajima K, Kanda T, Otsuki N, Nibu K, Sasaki R, Itoh T, Sugimura K. ${ }^{18} \mathrm{~F}-\mathrm{FDG}$ PET/CT imaging for detection of nodal metastases in patients with squamous cell carcinoma of the pharynx and larynx: comparison with CT. Jpn J Radiol 2016;34:203-210. 